\title{
A FIRST CLINICAL CASE REPORT OF WEST NILE VIRAL ENCEPHALITIS IN POLTAVA REGION OF UKRAINE
}

DOI: 10.36740/WLek202004141

\author{
Tetiana M. Kotelevska, Nataliia 0. Pryimenko, Halyna M. Dubynska, Olena M. Iziumska, Tetiana I Koval, \\ Kateryna V. Pikul, Tetiana Y. Purdenko \\ UKRAINIAN MEDICAL STOMATOLOGICAL ACADEMY, POLTAVA, UKRAINE
}

\begin{abstract}
West Nile Fever (WNF) is the most common arbovirus infection caused by West Nile Virus (WNV), which has been responsible for numerous epidemic outbreaks of disease among humans, birds and horses on all continents, with the exception of Antarctica, over the past two decades. On the territory of Ukraine, the earliest reports of cases of WNV circulation in humans and birds relate to the 70s of the XX century. In Poltava region WNF was first registered in 2011. Though the epidemiological and clinical patterns of WNF in Ukraine and Poltava region remain understudied, primarily due to the lack of alertness of practitioners to the problem of WNF and to broader access to laboratory diagnosis of the disease. The first clinical case of West Nile Viral encephalitis, registered on the territory of Poltava region, has been given and analyzed.
\end{abstract}

KEY WORDS: West Nile Viral, encephalitis, clinical case, Poltava region, Ukraine

Wiad Lek. 2020;73(4):831-834

\section{INTRODUCTION}

West Nile Fever (WNF) is a natural focal zoonotic arbovirus infection caused by West Nile Virus (WNV), which in severe cases is characterized by fever, inflammation of the meninges and the brain matter, lymphadenopathy, mucosal lesions and exanthema [1].

Over the last two decades, the virus has acquired an epidemic potential, due to rapid global spread, the formation of new natural foci and the ability to cause epidemics in endemic regions among humans, birds and horses in many parts of the world. [2,3]. At present WNV circulation has been confirmed in 20 European countries, including close to Ukraine - Romania, Russia, Poland, Hungary and Slovakia $[4,5]$. On the territory of Ukraine, the earliest reports of cases of WNV circulation in humans and birds relate to the 70 s of the XX century $[6,7,8]$. According to experts from the European Center for Disease Control, during the last decade the proportion of seropositive individuals to WNV among the population of the European Union varies from $2.1 \%$ to $10.6 \%$ [9]. In Poltava region the first time laboratory confirmed WNF cases were registered in 2011, and in general from 2011 to 2017 acute infection was diagnosed in 25 patients [10].

The virus is maintained in the enzootic environment between ornithophilic mosquitoes and certain species of birds with epizootic spread among animals, reptiles and humans [11]. Although the vast majority of patients are infected with WNV in a transmission way, through mosquito and tick bites, other mechanisms have been described, including blood transfusion [12], organ transplantation [13], the transplacental one, breastfeeding [14], as well as laboratory infection cases [15].
The study of the clinical course and epidemiological patterns of WNF is complicated by a large number of asymptomatic and subclinical forms, which generally make up $80-90 \%$ [11]. Conducted serological studies of WNF epidemics in North America and Europe have shown that approximately $20 \%$ of infected patients develop fever, and less than $1 \%$ have neuroinvasive diseases $[16,17,18]$.

In recent years, in response to the introduction of mandatory testing of donor blood on WNV in the USA, they have succeeded in studying the WNF symptom complex in more detail [19]. Thus, during 2003-2008, a parallel survey and laboratory examination of blood serum samples on RNA was performed in WNV 1436 donors, who had seropositive markers of the virus during the initial screening [20]. It's been found out that acute WNF occurred in 576 subjects, 150 of them $(26 \%)$ revealed clinical manifestations of the disease. The study revealed 8 symptoms - indicators of the disease, namely: headache, general weakness, fever, chills, severe muscle pain, joint pain, eye pain and rash [19]. An interesting fact was that almost half (44\%) of people diagnosed with acute infection had applied for medical aid on the eve of the day, but only 29 (5\%) were diagnosed with WNF [19].

In addition to the mentioned flu-like form, $1 \%$ of people may develop neuroinvasive disease associated with WNV in the form of meningitis, encephalitis, or acute flaccid paralysis $[21,22]$. WNV meningitis is characterized by fever, signs of irritation of the meninges, most often by rigidity of the occipital muscles, cerebral symptoms: severe headache, photophobia, nausea and vomiting; it is laboratory confirmed by changes in liquor, typical for aseptic serous meningitis [22]. WNV encephalitis manifests itself in a wide clinical range: from disturbances of 
consciousness to severe focal neurological injuries. As a rule, during the first days of the illness patients develop a high hyperthermia and severe intoxication syndrome, and from the 4th day signs of brain damage - anxiety, delirium, ataxia, tremor, sometimes seizures and coma are joined $[1,16,22,23]$. WNV encephalitis mortality is approximately $20 \%[24,25]$. According to statistics, acute flaccid paralysis occurs in $17.5 \%$ of patients with neuroinvasive manifestations of WNF and is characterized by a predominant lesion of the anterior horns of the spinal cord - paresis of the extremities, bladder dysfunction, respiratory failure $[26,27]$. Predictors of the development of neuroinvasive forms of WNF are a set of factors of the pathogen (the type of the involved WNV strain) and the patient (age over 60, alcohol abuse, the presence of concomitant diseases - diabetes mellitus, hypertension, chronic renal failure, cancer, HIV infection, etc.) $[25,28,29]$. In addition to febrile and neurological symptoms in WNF, other manifestations of the disease have been described - chorioretinitis [30], hepatitis [31], pancreatitis [32], myocarditis [33], myositis and orchitis [34].

The main criterion for the specific diagnosis of WNV is the determination of immunoglobulins of the $M$ class (IgM) in blood serum or spinal fluid in the dynamics (ELISA), which have become positive since the 5th day of the illness in $98 \%$ of patients [35]. Subsequently, seroconversion is observed, and immunoglobulins of the G class (IgG) in paired sera with an interval of 7-10 days are detected, the increase in their titre 4 times or more is considered to be the diagnostic one. In some patients specific WNV antibodies may be stored in serum for many years, which interferes the diagnosis and monitoring acute infection, especially in annual seasonal outbreaks [36, 37]. The false results of studying antibodies to WNV when infected with other arboviruses are also possible. Therefore, crucial in the diagnosis of WNF is determining the serological markers in paired sera. The PCR diagnosis with the determination of the WNV RNA is less practical, since WNF has a low viraemia of short duration $[1,11]$.

The epidemiological and clinical patterns of WNF in Ukraine and Poltava region remain understudied, primarily due to the lack of alertness of practitioners to the problem of WNF and to broader access to laboratory diagnosis of the disease. In connection with the above matter, particular attention is given to examples of first clinical case of West Nile Viral encephalitis among the residents of Poltava region.

\section{CLINICAL CASE}

The female patient, 57 years old, was hospitalized on the 8th day of illness into the diagnostic department of the Poltava Regional Clinical Infectious Disease Hospital with the diagnosis "Acute Respiratory Viral Infection? Enterovirus Infection?" At hospitalization there were complaints about an increase in body temperature up to $39.0^{\circ} \mathrm{C}$, chills, body pain, headache, dizziness, nausea, blurred and double vision, photophobia, chronic general weakness, rash. The patient became ill in early September, when there were weakness and muscle aches, since next day she had an increase in body temperature to subfebrile figures $\left(37.4^{\circ} \mathrm{C}\right)$. She was not under treatment and did not seek any medical help. During the following days there were any changes. The condition worsened on the 6 th day of the illness, when the body temperature increased to $39^{\circ} \mathrm{C}$, there were dizziness, photophobia, blurred and double vision, headache and weakness, nausea and recurrent diarrhea joined, pale pink skin trunk rash of erythematous and papular nature was noticed. She applied to Poltava Regional Clinical Infectious Disease Hospital and was hospitalized.

From the epidemiological history: the patient lives in the urban-type locality of Reshetylivka in Poltava region, in a private house on the river bank; she has noticed mosquito bites; for the last 2 weeks she has not left the place of residence; she denies contacts with infectious patients; the patient eats only at home; water supply is centralized.

Objective status during hospitalization: body temperature $38.0^{\circ} \mathrm{C}$, pulse of 83 beats per minute, blood pressure $-120 / 80 \mathrm{mmHg}$. General condition of moderate severity. $\mathrm{AAO}$. The skin is of normal color, there is a diffuse pale pink spotted papule rash without a tendency to fuse on the skin of the trunk and upper extremities. The mucous membrane of the oropharynx is hyperemic, swollen with an enlarged vascular pattern, no plaque. Cervical and submandibular lymph nodes up to $1.0 \mathrm{~cm}$ in diameter can be palpated, they are elastic and painless. No edema. Auscultation in the lungs indicates vesicular breathing with no wheezing. Heart tons are rhythmic, moderately weakened. The tongue is wet and coated. Abdomen is involved into the act of breathing, with palpation it's soft and painless. The liver and spleen are not palpable. Intestinal loops are sensitive when palpated and grumbling. Diuresis is adequate.

Neurological status: Awake. Eye gaps, pupils $\mathrm{D}=\mathrm{S}$, weakness of VI pair on both sides, diplopia when looking sidewards; the weakness of convergence on both sides. The nasolabial fold is smoothed to the right. Middle tongue. Arm reflexes (from the biceps, the triceps, carporadial) and the leg ones (knee and achilles) are high, abdominal ones are absent. Positive Babinski sign. Extremity strength $-5 / 5$, muscle tone is normal. Surface and deep sensitivity is not compromised. Coordinate tests are performed satisfactorily. Romberg's test - the patient is imbalanced. Meningeal signs are absent.

When examining the eyeground: $\mathrm{OD}=\mathrm{OS}$, the eyes are open, clear, the optical medium is transparent, the disk of the optic nerve - the borders are not clear due to edema of the retina, vessels are narrowed, convoluted, macular reflex is enlarged, at the time of examination hemorrhage was not detected.

At additional examination the following changes in the general analysis of blood were detected - neutrophilosis (10\%), elevated ESR $(17 \mathrm{~mm} / \mathrm{h})$; in the urogram there were traces of protein; in the biochemical blood test elevations in ALT (66.3 IU/L), AST (43.1 IU/L) and LDH (483.3 IU/L) were marked. Head MRI showed any pathological changes. The patient categorically refused to have a spinal puncture made. 
The previous diagnosis was established: "Fever of unknown origin. Viral encephalitis?" Observation in dynamics, examination in accordance with the protocol for the management of patients with fever, and treatment (antibiotics, immunoglobulin, detoxification, anti-edema and anti-inflammatory drugs, hepatoprotectors) were prescribed.

On the background of ongoing therapy in the dynamics the patient's condition improved: on the 3rd day body temperature became normal, manifestations of intoxication and cerebral syndromes (headache, dizziness, nausea) reduced, as well as neurological symptoms regressed, completely disappeared on the 4 th-5th days. However, on the 5th day of staying at hospital the patient noted a sudden deterioration of the condition - the body temperature increased to $39^{\circ} \mathrm{C}$ again, with a fever, general weakness, recurrent pronounced muscle pain and headache. The general blood analysis showed elevated ESR up to $20 \mathrm{~mm} / \mathrm{h}$ with the normal hemogram and biochemical blood test. Antipyretics were prescribed, and detoxification therapy was continued. Subsequently, the manifestation of the intoxication syndrome was regressed in 6 days, febrile fever lasted for 1 day and decreased litically in next 3 days. The rash completely regressed in 7 days, it disappeared without pigmentation and peeling. Manifestations of asthenic syndrome (weakness, fatigue) lasted for a month. The patient was discharged from hospital in a satisfactory condition on the 21st day of the illness.

According to the results of the research conducted, in the dynamics using ELISA IgM and IgG to WNV with an increase by 5 times in the titre of antibodies in paired sera were detected. Any other etiological factors of fever weren't found out. The final diagnosis was established: "West Nile Fever, neuroinvasive form (encephalitis with predominantly sternal localization, with bilateral reflex-pyramidal insufficiency, and liquor-hypertensive syndrome), of moderate severity".

\section{CONCLUSIONS}

The clinical case given demonstrates the typical course of neuroinvasive form of West Nile Fever in the type of encephalitis. The beginning of the registration of West Nile Fever cases in Poltava region should contribute to more active clinical and laboratory diagnosis of this disease in the summer-autumn period among patients with febrile conditions and central nervous system injuries, who noted mosquito or tick bites in the case history.

\section{REFERENCES}

1. Holubovska 0. .A. et al. OA Holubovska, MA Andreichyn Infectious diseases: textbook [for students of higher medical educational establishments]. K. : Medicine Publishing; 2018, p. 610-616.

2. Aharonson-Raz K., Lichter-Peled A., Tal S., et al. Spatial and Temporal Distribution of West Nile Virus in Horses in Israel (1997-2013) - from Endemic to Epidemics. PLoS One. 2014;9(11): e113149.

3. Vinohrad N.0., Shul U.A. Haryachka zakhidnoho Nilu — aktual'na infektsiya v Ukrayini [The West Nile Fever as an urgent problem in Ukraine]. Acta medica Leopoliensia. 2016; 22(2): 4-6. (In Ukrainian).
4. Hubálek Z. Mosquito-borne viruses in Europe. Parasitology Research. 2008;103(1):29-43.

5. Niczyporuk J., Samorek-Salamonowicz E., LecollinetS. et al. Occurrence ofWest NileVirus Antibodies in Wild Birds, Horses, and Humans in Poland Biomed Res Int. 2015; 2015: 234181. doi: 10.1155/2015/234181.

6. Sidenko V.P., Stepankovskaia L.D.,Solomko R.M. etal. Rezultatyiissledovaniya lihoradki Zapadnogo Nila na yuge evropeyskoy chasti SSSR [Results of a study of West Nile fever in the South of the European part of the USSR]. Zh. Mikrobiol. Epidemiol. Immunobiol. 1974;00:129. (In Russian).

7. Buletsa B.A., Turak I.A., Korol M.I. et al. Nevrologicheskie proyavleniya zapadno-nilskoy lihoradki v Zakarpatskoy oblasti [Neurologic manifestations of West Nile fever in the Transcarpathian region]. Zh. Nevropatol. Psikhiatr. Im. S. S. Korsakova. 1989;89:29-30. (In Russian).

8. Vinograd I.A., Beletskaia G.V., Chumachenko S.S. et al.Vyidelenie virusa Zapadnogo Nila na yuge Ukrainyi [lsolation of West Nile virus in the Southern Ukraine]. Vopr. Virusol. 1982; 27: 567-569. (In Russian).

9. Centers for Disease Control and Prevention. West Nile virus. Final annual maps and data for 1999-2016. Available: http://www.cdc. gov/westnile/statsMaps/finalMapsData/index.html.

10. Koval T..., Kotelevska T.M., Dubynska H.M. etal. Osobennosti diagnostiki i techeniya lihoradki Zapadnogo Nila v Poltavskoy oblasti [Diagnostic features and the course of the West Nile fever in Poltava region]. Clinical infectology and parasitology. 2019; 8(1): 125-126. (In Russian).

11. Timothy J.G., Cameron E.W. A review of the epidemiological and clinical aspects of West Nile virus. Int J Gen Med. 2014; 7: 193-203.

12. Pealer L.N., Marfin A.A., Petersen L.R. et al. West Nile Virus Transmission Investigation Team Transmission of West Nile virus through blood transfusion in the United States in 2002. N Engl J Med. 2003;349(13):1236-1245

13. Nett R.J., Kuehnert M.J., Ison M.G. et al. Current practices and evaluation of screening solid organ donors for West Nile virus. Transpl Infect Dis. 2012;14(3):268-277.

14. O'Leary D.R., Kuhn S., Kniss K.L. et al. Birth outcomes following West Nile Virus infection of pregnant women in the United States: 2003-2004. Pediatrics. 2006;117(3):e537-e545.

15. Venter M., BurtF.J., Blumberg L. et al. Cytokine induction after laboratoryacquired West Nile virus infection. N Engl J Med. 2009;360(12):1260-1262.

16. Mostashari F., Bunning M.L., Kitsutani P.T. et al. Epidemic West Nile encephalitis, New York, 1999: results of a household-based seroepidemiological survey. Lancet. 2001; vol.358:261-264.

17. Solomon T. Flavivirus encephalitis. N Engl J Med. 2004;351(4):370-378.

18. Hubálek Z. Comparative symptomatology of West Nile fever. Lancet. 2001;358(9278):254-255.

19. Zou S., Foster G.A., Dodd R.Y. et al. West Nile fever characteristics among viremic persons identified through blood donor screening. J Infect Dis. 2010;202(9):1354-1361.

20. Orton S.L., Stramer S.L., Dodd R.Y. Self-reported symptoms associated with West Nile virus infection in RNA-positive blood donor, Transfusion, 2006, vol.46 2: 272-277.

21. Carson P.J., Borchardt S.M., Custer B. et al. Neuroinvasive disease and West Nile virus infection, North Dakota, USA, 1999-2008. Emerg Infect Dis. 2012;18(4):684-686.

22. Kramer L.D., LiJ., Shi P.Y.West Nile virus. Lancet Neurol. 2007;6(2):171-181.

23. James J. Sejvar. Clinical Manifestations and Outcomes of West Nile Virus Infection. Viruses. 2014 Feb; 6(2): 606-623.

24. Bode A.V., Sejvar J.J., PapeW.J. et al. West Nile virus disease: a descriptive study of 228 patients hospitalized in a 4-county region of Colorado in 2003. Clin Infect Dis. 2006;42(9):1234-1240. 
25. Danis K., Papa A., Theocharopoulos G. et al. Outbreak of West Nile virus infection in Greece, 2010. Emerg Infect Dis. 2011;17(10):1868-1872.

26. Téllez-Zenteno J.F., Hunter G., Hernández-Ronquillo L. et al. Neuroinvasive West Nile virus disease in Canada. The Saskatchewan experience.Can J Neurol Sci. 2013;40(4):580-584.

27. Leis A.A., Stokic D.S. Neuromuscular manifestations of West Nile virus infection. Front Neurol. 2012;3:37.

28. Carson P.J., Borchardt S.M., Custer B. et al. Neuroinvasive disease and West Nile virus infection, North Dakota, USA, 1999-2008. Emerg Infect Dis. 2012;18(4):684-686.

29. Petersen L.R., Brault A.C., Nasci R.S. West Nile virus: review of the literature. JAMA. 2013;310(3):308-315.

30. Khairallah M., Ben Yahia S., Ladjimi A. et al. Chorioretinal involvement in patients with West Nile virus infection. Ophthalmology. 2004;111(11):2065-2070.

31. Georges A.J., Lesbordes J.L., Georges-Courbot M.C. et al. Fatal hepatitis from West Nile virus. Ann Inst Pasteur Virol. 1987;138(2):237-244.

32. Perelman A., Stern J. Acute pancreatitis in West Nile Fever. Am J Trop Med Hyg. 1974;23(6):1150-1152.

33. Pergam S.A., DeLong C.E., Echevarria L. et al. Myocarditis in West Nile Virus infection. Am J Trop Med Hyg. 2006;75(6):1232-1233.

34. Smith R.D., Konoplev S., DeCourten-Myers G. et al. West Nile virus encephalitis with myositis and orchitis. Hum Pathol. 2004;35(2):254-258.

35. Tilley P.A., Fox J.D., Jayaraman G.C. et al. Nucleic acid testing for west nile virus RNA in plasma enhances rapid diagnosis of acute infection in symptomatic patients. J Infect Dis. 2006;193(10):1361-1364.

36. Murray K.O., Garcia M.N., Yan C. et al. Persistence of detectable immunoglobulin $M$ antibodies up to 8 years after infection with West Nile virus. Am J Trop Med Hyg.2013;89(5):996-1000.

37. Papa A., Danis K., Athanasiadou A. et al. Persistence of West Nile virus immunoglobulin Mantibodies, Greece.J MedVirol.2011;83(10):1857-1860.
The work was performed within the framework of the initiative research of the Department of Infectious Diseases with UMSA Epidemiology "Optimization of therapeutic and diagnostic tactics for infectious diseases of viral, bacterial, parasitic etiology and their mixtures based on the study of their clinical and pathogenetic". (0113U005006).

\section{ORCID and contributionship:}

Tetiana M. Kotelevska - 0000-0001-7508-4876 ${ }^{A, B, D, E}$

Nataliia O. Pryimenko - 0000-0002-8265-1143 B,C

Halyna M. Dubynska - 0000-0003-0950-8997 A,E,F

Olena M. Iziumska - 0000-0002-9480-8988 ${ }^{B, D}$

Tetiana I. Koval - 0000-0003-2685-8665 C,E,F

Kateryna V. Pikul - 0000-0002-5724-4343 ${ }^{\text {B,D }}$

Tetiana Y. Purdenko - 0000-0002-3561-4331 D,E

\section{Conflicts of interest:}

Authors declare no conflict of interest.

\section{CORRESPONDING AUTHOR Tetiana M. Kotelevska}

Department of Infectious Diseases with Epidemiology,

Ukrainian Medical Stomatological Academy,

23 Shevchenko Str., Poltava 36004, Ukraine

tel: +380505910186

e-mail:kotelevska.tetiana@gmail.com

Received: 26.07.2019

Accepted: 04.02.2020
A - Work concept and design, B - Data collection and analysis, C - Responsibility for statistical analysis, D-Writing the article, $\mathbf{E}$-Critical review, F - Final approval of the article 